A. B. Антипова. Междисциплинарные аспекты проблемы детско-подросткового суицида (по материалам Забайкальского края)

Научная статья

УДК 343.614(571.55)

DOI 10.18101/2658-4409-2021-2-31-38

\title{
МЕЖДИСЦИПЛИНАРНЫЕ АСПЕКТЫ ПРОБЛЕМЫ \\ ДЕТСКО-ПОДРОСТКОВОГО СУИЦИДА \\ (по материалам Забайкальского края)
}

\section{(C) Антипова Анна Васильевна}

подполковник полиции, заместитель начальника отдела участковых уполномоченных подразделения по делам несовершеннолетних отдела МВД России по Закаменскому району Республики Бурятия Россия, 671950, г. Закаменск, ул. Конституции, 12 annetta.qwerty.antipova@mail.ru

\begin{abstract}
Аннотация. Статья посвящена проблеме детской и подростковой смертности от самоубийств. Изучается статистика детско-подросткового суицида в рамках мониторинга как эффективного инструмента профилактики суицидального поведения на примере Забайкальского края. Определены особенности расследования уголовных дел данной категории. Перечислены причины и основные факторы, способствующие совершению самоубийств несовершеннолетних. Рассмотрены меры по профилактике и предупреждению суицидального поведения среди подростков, а также комплекс мероприятий, проводящихся на территории Забайкальского края в целях предотвращения суицидов детей.
\end{abstract}

Ключевые слова: проблема детского суицида, расследование дел по фактам детского суицида, криминогенные факторы детского суицида, подростковый суицид, причины самоубийств, профилактика суицидального поведения

\section{Для цитирования}

Антипова A. B. Междисциплинарные аспекты проблемы детско-подросткового суицида (по материалам Забайкальского края) // Вестник Бурятского государственного университета. Юриспруденция. 2021. Вып. 2. С. 31-38.

Забайкальский край входит в число регионов с высоким уровнем смертности от самоубийств. За последние 5 лет в Забайкальском крае отмечается снижение смертности от суицидов среди населения на $32,9 \%$ :

2014 г. — 47,7 на 100 тыс. населения (519 чел.);

2015 г. - 50,1 на 100 тыс. населения (544 чел.);

2016 г. — 38,9 на 100 тыс. населения (424 чел.);

2017 г. - 39,9 на 100 тыс. населения (423 чел.);

2018 г. - 32,3 на 100 тыс. населения (348 чел.).

Сегодня регион входит в группу субъектов Российской Федерации со средним показателем смертности населения по данному показателю.

Частота завершенных суицидов в Забайкальском крае в 2,7 раза выше среднероссийского показателя и в 1,6 раза выше, чем в Дальневосточном федеральном округе. 
Весьма актуальной проблемой является суицидальное поведение подростков. Забайкальский край входит в группу регионов с высоким уровнем смертности от самоубийств среди подростков.

Приведем показатели смертности от самоубийств среди малолетних (до 14 лет): 2014 г. - 2,7 на 100 тыс. населения (6 детей);

2015 г. - 2,2 на 100 тыс. населения (5 детей);

2016 г. - 3 на 100 тыс. населения (7 детей);

2017 г. - 0,86 на 100 тыс. населения (2 детей);

2018 г. - 1,72 на 100 тыс. населения (4 детей).

Показатели смертности от самоубийств среди подростков (15-17 лет):

2014 г. — 48,2 на 100 тыс. населения (19 подростков);

2015 г. — 46,3 на 100 тыс. населения (17 подростков);

2016 г. — 40,5 на 100 тыс. населения (15 подростков);

2017 г. — 41,1 на 100 тыс. населения (15 подростков);

2018 г. - 32,9 на 100 тыс. населения (11 подростков).

За 9 месяцев 2019 г. в структурные подразделения следственного управления поступило 124 сообщения о попытках суицида несовершеннолетних (АППГ-85); 12 подростков погибли в результате совершения суицидов (АППГ-12), все в возрасте 14-17 лет. По состоянию на 12.11.2019 г. в крае зарегистрировано 16 завершенных суицидов.

По 10 фактам завершенных суицидов несовершеннолетних возбуждены уголовные дела. В 2 случаях приняты решения об отказе в возбуждении уголовного дела.

Особенности проведения проверок и расследования уголовных дел данной категории заключаются в необходимости установления причин, побудивших несовершеннолетнего совершить самоубийство.

С этой целью устанавливаются и опрашиваются не только родственники несовершеннолетнего, которые совместно с ним проживали, но и его знакомые, сверстники, работники образовательного учреждения, где несовершеннолетний проходил обучение, и т. д.

При получении объяснений от указанных лиц в обязательном порядке, кроме основных обстоятельств произошедшего, выясняются условия жизни и воспитания несовершеннолетнего, наличие либо отсутствие фактов негативного на него влияния со стороны родителей, родственников, знакомых и сверстников, выясняется наличие либо отсутствие систематичности его унижения со стороны кого-либо.

Следователи изучают личность каждого несовершеннолетнего, требуют сведения о постановке на учет в психоневрологический и наркологический диспансеры; сведения о том, состоит ли несовершеннолетний на учете в подразделении по делам несовершеннолетних органа внутренних дел, рапорт-характеристику от сотрудника ПДН; сведения из информационного центра органа внутренних дел (в случае достижения 14-летнего возраста) в отношении несовершеннолетнего; характеристику с места жительства и работы в отношении родителей несовершеннолетних; акт обследования семейно-бытовых условий жизни несовершеннолетнего; сведения комиссии по делам несовершеннолетних и защите их прав 
A. B. Антипова. Междисциплинарные аспекты проблемы детско-подросткового суицида (по материалам Забайкальского края)

администрации района; характеристику из учебного заведения в отношении несовершеннолетнего.

В рамках процессуальных проверок и расследования уголовных дел следователями в адрес органов системы профилактики вносятся представления и направляются информационные письма о необходимости принятия мер профилактического характера к подросткам.

По результатам рассмотрения информации и представлений ряд подростков поставлены на внутришкольный учет, за ними закреплены общественные воспитатели, проведена психологическая диагностика, а некоторые подростки направлены к детскому психологу, а также в психоневрологический диспансер.

В большинстве случаев попытки суицидов совершали лица женского пола в возрасте от 13 до 17 лет, при этом лишь некоторые ранее совершали попытки суицидов, действия указанных лиц носили демонстративный характер как форма протеста против запретов родителей, которые ставились последними в воспитательных целях, либо как последствие неопределенности в жизни, а также из-за ссор со сверстниками. Имели место факты совершения попыток суицида из-за внутренних переживаний и стресса в связи с опасением несдачи государственной итоговой аттестации. Также имели место случаи совершения суицидов несовершеннолетними лицами мужского пола из-за ссор с девушками, а также конфликтов в семье. Большинство лиц, совершивших суицид, учились удовлетворительно, без энтузиазма; влияние СМИ, субкультур или интернет-сообществ на совершение попыток суицида в ходе проверок не установлено. Случаев демонстрации суицидальных намерений несовершеннолетними, совершившими суицид, не имелось.

Причины (мотивы) совершения несовершеннолетними лицами суицидов можно условно разделить на несколько основных групп. К первой группе причин, установленных в ходе проверочных мероприятий, по которым несовершеннолетние лица совершают суицид, относится неблагоприятно складывающиеся для них взаимоотношения со сверстниками, противоположным полом - «неразделенная любовь». Ко второй группе причин относятся неблагоприятные взаимоотношения между детьми и родителями, конфликты в семье, желание несовершеннолетних быть «свободными» в выборе поведения, общения и т. д., при наличии определенного контроля за их поведением со стороны взрослых, а также отсутствие в семьях материального достатка, злоупотребление взрослыми спиртными напитками.

К третьей группе причин относятся внутренние переживания несовершеннолетних, связанные с уходом из жизни их родственников либо близких им людей.

К четвертой группе причин относятся привлечение несовершеннолетних к уголовной либо иной ответственности, боязнь последних наказания за совершенные ими преступления.

Социальный профиль несовершеннолетних, покончивших жизнь самоубийством, формируется за счет учащихся, в том числе студентов, а также не занятых социально-полезной деятельностью подростков, детей с девиантными формами поведения и рисками, из них вытекающими (например, употребление спиртных напитков, запрещенных препаратов), а также ввиду отсутствия воспитательной работы, любви в семье.

Основные факторы, способствующие совершению самоубийств несовершеннолетних: неблагополучные семьи; конфликты с родителями, любовные 
конфликты, конфликты со сверстниками; наличие непосредственно пропагандирующих самоубийство ресурсов в интернете и коммуникативных социальных сетях; засилие жестокости и криминала на телевидении, приводящее к внедрению в сознание подростков представлений об «обыденности» насилия и смерти, в том числе убийства и самоубийства; школьные проблемы (особенно для подростков с невысоким интеллектом, сочетающимся с выраженной чувствительностью и уязвимостью); сексуальные проблемы, дополненные другими факторами, могут стать причиной дезадаптивного поведения, ведущего к суициду; депрессия; стресс; незрелость личности и определенные черты характера.

Один из указанных факторов редко может явиться достаточной причиной самоубийства. В связи с этим требуется всесторонняя поддержка подростков, а не только исправление отдельно возникшей ситуации или проблемного поведения.

С целью профилактики суицидального поведения среди подростков на территории края реализуется комплекс мероприятий, участие в ряде которых принимает и следственное управление. Так, с 2018 г. проводится оперативный мониторинг случаев завершенных суицидов и суицидальных попыток с учетом половозрастной структуры в разрезе муниципальных образований, что дает возможность анализа эпидемиологической ситуации по суицидальной активности на территории Забайкальского края.

В апреле 2018 г. по инициативе следственного управления принято постановление Комиссии по делам несовершеннолетних и защите их прав об утверждении «Порядка межведомственного взаимодействия специалистов в случае незавершенного суицида несовершеннолетнего с целью предупреждения рецидивного поведения и стабилизации психологического состояния ребенка».

В рамках заседания Комиссии по делам несовершеннолетних на методической площадке проведен практический семинар (в работе семинара принял участие сотрудник следственного управления) по вопросам межведомственного взаимодействия при осуществлении первичной, вторичной и третичной профилактики кризисных состояний и суицидального поведения несовершеннолетних.

В целях предотвращения фактов суицидов детей от участия в деструктивных играх в рамках расследуемых уголовных дел инициируется проведение заседаний межведомственной рабочей группы при заместителе прокурора края по вопросам выявления и пресечения на территории края действий групп суицидальной направленности. Наряду с заинтересованными ведомствами участие в группе принимают представители регионального управления Роскомнадзора, а также волонтерских организаций.

Вопросы предупреждения суицидального поведения и вовлечения несовершеннолетних в «группы смерти» и иные деструктивные группы в социальных сетях рассматривались на заседании Комиссии по делам несовершеннолетних Забайкальского края, где рассмотрен механизм выявления подростков, вовлеченных в суицидальные группы, разработана методика действий каждого ведомства (перечень необходимых действий со стороны родителей, волонтерских, образовательных и медицинских организаций в случае установления фактов участия несовершеннолетних в суицидальных играх, порядок взаимодействия с правоохранительными органами). 
A. B. Антипова. Междисциплинарные аспекты проблемы детско-подросткового суицида (по материалам Забайкальского края)

По вопросам обеспечения гарантий государственной защиты прав и свобод детей, совершенствования законодательства о правах несовершеннолетних, организации правового просвещения и правовой помощи несовершеннолетним следственным управлением заключено Соглашение о сотрудничестве с уполномоченным по правам ребенка в Забайкальском крае.

Заключены соглашения о сотрудничестве с Министерством здравоохранения края, Главным управлением МЧС по Забайкальскому краю, Забайкальским краевым отделением Всероссийской общественной организации «Союз добровольцев России».

В целях предупреждения суицидов среди населения края Министерством здравоохранения Забайкальского края реализуются следующие мероприятия. Для помощи лицам с кризисными состояниями и суицидальным поведением на базе ГКУЗ «Краевая клиническая психиатрическая больница им. В. Х. Кандинского» работает Кризисная служба.

В структуру кризисной службы входят:

- отделение «Телефон доверия» - работает круглосуточно, анонимно, бесплатно;

- кабинет медико-социально-психологической помощи - работает ежедневно с 8-00 до 15-42 (выходной - суббота, воскресенье), анонимно, бесплатно;

- выездные специализированные психологические бригады.

В Кризисной службе всем обратившимся несовершеннолетним проводятся психологическая диагностика, психологическое консультирование, психотерапия; несовершеннолетним с суицидальным поведением (высказывания, мысли, тенденции, попытки) проводится экспресс-диагностика суицидального риска «Сигнал» и опросник антисуицидальных попыток.

Подготовлены методические рекомендации для работников образования «Суицидальное поведение на территории Забайкальского края: эпидемиология, типология, факторная обусловленность, профилактика, диагностика и превенция», адресованные директорам образовательных учреждений, заместителям директоров по воспитательной работе, психологам, социальным педагогам, педагогам-психологам, классным руководителям.

В методических рекомендациях излагаются основы понимания суицидального поведения, его причины, типология, факторы риска, сведения об уровне суицидов в Забайкальском крае. Изложены рекомендации по предупреждению суицидального поведения.

Оказывается квалифицированная психологическая, психотерапевтическая, психиатрическая помощь подросткам по вопросам, связанным с посещением сайтов, пропагандирующих самоубийства.

Разработан региональный комплекс мер по снижению смертности населения от самоубийств, в том числе среди несовершеннолетних, на период 2017-2020 гг.

Утвержден Порядок межведомственного взаимодействия специалистов в случае незавершенного суицида несовершеннолетнего с целью предупреждения рецидивного поведения и стабилизации психологического состояния ребенка. Определена маршрутизация подростков с кризисными состояниями и суицидальным поведением. Разработан механизм информационного взаимодействия при оказании 
медицинской помощи лицам с кризисными состояниями и суицидальным поведением», которым определен порядок регистрации, хранения данных о суицидальных попытках и ведения краевого регистра лиц с суицидальным поведением, в том числе детей до 17 лет включительно.

В комплексный план мероприятий Министерства здравоохранения Забайкальского края, направленных на снижение смертности и заболеваемости, повышение рождаемости и формирование здорового образа жизни населения Забайкальского края, включен пункт о реализации образовательных программ для мониторинга душевного неблагополучия детей в рамках проведения родительских собраний на постоянной основе.

Специалисты принимают участие в общешкольных и районных родительских собраниях по проблемам образования, воспитания, успешной социализации, профилактики девиантного поведения детей, детско- родительских взаимоотношений; ситуации распространения в сети Интернет негативной информации, пропагандирующей самоубийства подростков, а также факты вовлечения несовершеннолетних в соответствующие группы и сообщества в социальных сетях.

Министерством здравоохранения Забайкальского края издан приказ от 24.01.2018 г. № 93/p, предусматривающий обязанность информирования правоохранительных органов администрацией ГКУЗ «Краевая клиническая психиатрическая больница им. В. Х. Кандинского» о всех случаях госпитализации несовершеннолетних после попыток суицидов. По всем поступившим сообщениям организовано проведение процессуальных проверок.

В системе образования Забайкальского края выстроена система первичной профилактики жестокого обращения в отношении несовершеннолетних, где основой является просвещение учащихся, родителей и педагогов в области предотвращения насилия над детьми и подростками. Молодежными проектами, акциями, инициативами, месячниками правовых знаний охвачено в 2017/18 учебном году более 132000 обучающихся.

Школьными педагогами-психологами осуществляется обучение несовершеннолетних способам недопущения психологической манипуляции и формирование сознательного отношения к личной безопасности. Ежегодно проводится более 50000 социально-психологических тренингов.

Для недопущения возникновения и развития конфликтных ситуаций в образовательных организациях сформировано 313 Служб школьной медиации/примирения. Специалисты ведут целенаправленную работу по обучению школьников, родителей навыкам эффективного поведения и конструктивного разрешения конфликтов.

Реализуется комплекс дополнительных мер, направленных на профилактику девиантного поведения обучающихся общеобразовательных организаций (приказ Минобразования Забайкальского края от 19.02.2018 г. № 174), включающий превентивные мероприятия, психолого-педагогическое сопровождение обучающихся, работу с кризисным состоянием несовершеннолетних.

В целях повышения квалификации педагогов по профилактической деятельности разработан спецкурс «Профилактика детских и подростковых суицидов в образовательном учреждении»»,, который является обязательным для всех 
A. B. Антипова. Междисциплинарные аспекты проблемы детско-подросткового суицида (по материалам Забайкальского края)

категорий руководителей образовательных организаций и педагогических работников при прохождении курсов повышения квалификации начиная с 2012 г. Ежегодно более 5000 педагогов проходят обучение по данному курсу. Индивидуальная консультативная помощь (в том числе в дистанционном режиме) по вопросам профилактики детских и подростковых суицидов в образовательном учреждении оказывается ежегодно более 250 педагогам.

Важным направлением профилактической деятельности является мониторинг СМИ, а также соцсетей на предмет выявления сведений о совершении происшествий и преступлений в отношении несовершеннолетних.

Следственное управление и в дальнейшем нацелено на совершенствование работы во взаимодействии с другими заинтересованными органами по профилактике суицидального поведения несовершеннолетних.

\section{Литература}

1. Бычкова А. М., Раднаева Э. Л. Доведение до самоубийства посредством использования интернет-технологий: социально-психологические, криминологические и уголовно-правовые аспекты // Всероссийский криминологический журнал. 2018. Т. 12, № 1. С. 101-115. Текст : непосредственный.

2. Долгова Т. А. Психология суицидального поведения // Человек: преступление и наказание : материалы научно-теоретической конференции. Рязань : Изд-во Акад. права и управления Минюста России, 2004. С. 168-170. Текст : непосредственный.

3. Ермолаева Е. Г. Самоубийство как форма девиантного поведения личности // Сборник статей молодых ученых. Саратов : Изд-во СЮИ МВД России, 2006. Вып. 2. С. 65-71. Текст : непосредственный.

Статья поступила в редакцию 15.04.2021; одобрена после рецензирования 17.05.2021; принята к публикачии 22.06.2021.

\section{INTERDISCIPLINARY ASPECTS OF THE PROBLEM \\ OF CHILD AND ADOLESCENT SUICIDE \\ (a case study of Zabaikalsky Krai)}

Anna V. Antipova

Police Lieutenant Colonel,

Deputy Head of Community Policemen Division of Department on Juvenile Affairs under the Office of the Ministry of Internal Affairs of Russia in Zakamensk District of the Republic of Buryatia

12 Constitutsii St., Zakamensk 671950, Russia

annetta.qwerty.antipova@mail.ru

Abstract. The article is devoted to the problem of child and adolescent suicide mortality. It studies the statistics of child and adolescent suicide in Zabaikalsky Krai within the framework of monitoring as an effective tool for prevention of suicidal behavior. We have determined the peculiarities of investigation of the criminal cases of this category, considered the reasons and main factors contributing to juvenile suicide. The article also 
present the measures for prevention of suicidal behavior among adolescents, as well as a set of measures carried out on the territory of Zabaykalsky Krai in order to prevent child suicides.

Keywords: problem of child suicide, investigation of the cases of child suicide, criminogenic factors of child suicide, adolescent suicide, causes of suicide, prevention of suicidal behavior

\section{For citation}

Antipova A. V. Interdisciplinary Aspects of the Problem of Child and Adolescent Suicide. Bulletin of Buryat State University. Law. 2021; 2: 31-38 (In Russ.).

The article was submitted 15.04.2021; approved after reviewing 17.05.2021; accepted for publication 22.06.2021. 